\title{
Sinergitas Aktualisasi Bela Negara dan Kearifan Lokal dalam Meningkatkan Rasa Nasionalisme
}

\author{
Nurdiyana $^{\text {a,1* }}$, Endang Prastini ${ }^{\mathrm{b}, 2}$ \\ a,b Program Studi Pendidikan Pancasila dan Kewarganegaraan, Fakultas Keguruan dan Ilmu Pendidikan \\ Universitas Pamulang Kota Tangerang Selatan \\ 1dosen02080@unpam.ac.id, ${ }^{2}$ dosen01912@unpam.ac.id \\ *korespondensi penulis
}

Naskah diterima: 27 Juli 2020, direvisi: 1 Agustus 2020, disetujui: 3 September 2020

\begin{abstract}
Abstrak
Perkembangan zaman dan teknologi yang ada saat ini membawa dampak buruk pada perkembangan remaja. Sebagai upaya untuk pencegahan dari dampak buruk tersebut, maka perlu dilakukan suatu kegiatan seperti penyuluhan terkait dengan upaya untuk meningkatkan rasa nasionalisme pada remaja. Salah satu wujud dari rasa nasionalisme tersebut melalui pemahaman remaja akan pentingnya sinergitas bela negara dan kearifan lokal dikalangan remaja, dimana remaja yang menjadi sasaran dalam kegiatan ini adalah remaja yang tergabung dalam karang taruna di Pulau Untung Jawa Kepulauan Seribu. Hasil pengabdian kepada masyarakat ini menunjukkan bahwa adanya perubahan remaja karang taruna kearah yang positif, dibuktikan dengan kecintaan remaja terhadap tanah air dengan cara mempertahankan kearifan lokal yang mereka miliki, serta membentuk karakter yang baik dalam diri mereka.
\end{abstract}

Kata-kata kunci: Bela Negara; Kearifan Lokal; Rasa Nasionalisme

Abstract
The development of the times and the technology that exists today has an adverse impact
on the development of adolescents. As an effort to prevent the adverse effects, it is
necessary to conduct an activity such as counseling related to efforts to increase the
sense of nationalism in adolescents. One form of the sense of nationalism is through the
understanding of youth of the importance of synergy of state defense and local wisdom
among teenagers, where teenagers who are targeted in this activity are teenagers who
joined the cadet reef on the Island of Untung Jawa Kepulauan Seribu. The result of this
community service shows that there is a change of youth coral cadets in a positive
direction, evidenced by the love of youth towards the country by maintaining their local
wisdom, as well as forming a good character in them.

Keywords: defending the country; local wisdom; a sense of nationalism 


\section{PENDAHULUAN}

Berbagai permasalahan yang sedang dihadapi oleh bangsa Indonesia saat ini sangatlah kompleks, salah satunya memudarnya semangat nasionalisme. Masa sebelum kemerdekaan, para pemuda berjuang bersama mengangkat senjata untuk membebaskan negeri ini dari para penjajah dengan mempertaruhkan nyawanya. Hal tersebut mereka lakukan karena dorongan rasa nasionalisme dan jiwa patriotisme yang tinggi untuk negara.

Seiring dengan perkembangan zaman, sikap nasionalisme remaja saat ini semakin memudar, hal ini dikarenakan dampak negatif dari pesatnya perkembangan teknologi yang ada, dimana budaya luar akan dengan mudah masuk ke dalam negeri. Hal demikian sangat perlu untuk diantisipasi agar sikap nasionalisme para remaja ini tetap tinggi dengan menunjukkan kecintaannya kepada bangsa dan negara.

Jiwa dan rasa nasionalisme yang dulu tertanam kuat di diri bangsa Indonesia kini perlahan-lahan akan tergantikan dengan adat dan budaya yang kurang baik bagi pembentukan karakter bangsa ini, seperti contohnya banyak para remaja yang lebih bangga menggunakan produk-produk dengan brand dari luar negeri.
Jiwa nasionalisme yang membara yang telah ditorehkan dan dibuktikan lewat tinta sejarah pada waktu perjuangan merebut kemerdekaan akan terbuang sia-sia. Hal ini harus dapat disikapi oleh para remaja, karena masa depan negara ini tergantung pada mereka.

Nasionalisme sangat penting terhadap kehidupan berbangsa dan bernegara, karena hal ini merupakan wujud dari kecintaan dan kehormatan bangsa Indonesia. Dengan hal itu, remaja di Indonesia dapat melakukan sesuatu yang terbaik bagi bangsanya, menjaga keutuhan persatuan bangsa dan juga meningkatkan martabat dan citra bangsa Indonesia di hadapan dunia.

Salah satu wujud dari sikap nasionalisme para remaja adalah dengan melakukan bela negara dan mencintai kearifan lokal masing-masing daerah. Wujud bela negara saat sebelum kemerdekaan adalah dengan ikut berperang untuk melepaskan diri dari penjajah, namun masa setelah kemerdekaan saat ini wujud bela negara para remaja dapat dilakukan dengan mengisi kemerdekaan ini dengan hal-hal positif.

Bela negara sebagai sebuah perilaku, sikap serta tindakan yang dilakukan oleh warga negara yang didorong karena kecintaannya kepada negara yang didasarkan pada Pancasila dan UUD 1945 yang bertujuan 
untuk kelangsungan hidup bangsa dan negara seutuhnya. Selain itu, kearifan lokal dianggap sebagai sesuatu yang penting untuk pegangan hidup masyarakat dan sebagai dasar untuk seseorang berhubungan dengan orang lain, alam, dan kehidupan. Pada suku atau komunitas apapun di Indonesia. Secara garis besar kearifan lokal dapat memperkokoh semangat bela negara sehingga mendukung terwujudnya rasa nasionalisme warga negara.

Menurut Subagyo (2015), "Bela negara adalah sebuah konsep yang menarik untuk didiskusikan di era globalisasi saat ini. Era globalisasi mengancam eksistensi bangunan nasionalisme dan fondasi negara bangsa telah mendorong semua pihak untuk menekankan kepada pentingnya bela negara bagi warga negaranya. Setiap warga negara diminta untuk selalu berpikir, bertindak, berjuang dan berupaya membela negara. Harus ada hubungan timbal balik antara negara dan warga negara, dimana negara memberikan keamanan (security) dan kesejahteraan (prosperity) kepada warga negara. Sedangkan warga negara harus memberikan pembelaan ketika negara dalam kondisi terancam oleh ancaman musuh yang langsung atau tidak langsung menyerang bangunan negara.

\section{Undang-Undang Dasar Negara}

Republik Indonesia Tahun 1945 mengatur mengenai upaya bela negara yaitu ketentuan Pasal 27 Ayat (3) :" Setiap warga negara berhak dan wajib ikut serta dalam upaya pembelaan negara", dan dalam Pasal 30 Ayat (1) : "Tiap-tiap warga negara berhak dan wajib ikut serta dalam usaha pertahanan dan keamanan negara.

Pulau Untung Jawa yang merupakan salah satu dari pulau yang berpenduduk yang berada di gugusan kepulauan seribu Jakarta.Akses untuk bisa sampai ke lokasi ini melalui penyeberangan yang bisa dilakukan dari empat dermaga, yaitu dermaga barat yang menjadi pusat turun naiknya penumpang dari dan ke pantai tanjung pasir Tangerang. Dermaga barat ini kondisinya cukup bagus. Kedua dermaga tengah yang kecil, dermaga ini menjadi tempat singgah bagi kapal-kapal dari ancol dan muara karang. Ketiga dermaga tengah yang besar, yang menjadi tempat sandar kapal ukuran besar, karena dermaga ini mempunyai air yang cukup dalam. Terakhir dermaga timur, dermaga ini merupakan dermaga yang paling sepi karena posisi yang terletak di bagian timur pulau maka dermaga ini terlindung dari angin barat yang kencang.

Pulau Untung Jawa sebagai desa wisata nelayan memiliki pemandangan alam yang cukup baik, yang sebagian besar penduduknya bermata pencaharian sebagai nelayan. Pulau Untung Jawa merupakan bagian dari kepulauan administratif Kepulauan Seribu yang dihuni dengan kurang 
lebih 2.264 jiwa pada tahun 2017 dengan luas wilayah $1.03 \mathrm{~km}^{3}$. Banyaknya destinasi wisata ke Indonesia dan dapat menjadi lahan penghasilan warga sekitar wisata tersebut. Dengan pembinaan yang baik kepada warga sekitar dapat membuat destinasi wisata Indonesia menjadi lebih rapi dan modern yang membuat para wisatawan lokal maupun asing nyaman dalam mengunjungi tempat wisata yang ada di Indonesia.

\section{METODE}

Pengabdian kepada masyarakat ini menggunakan metode pendidikan masyarakat dalam bentuk penyuluhan yang bertujuan untuk meningkatkan pemahaman remaja karang taruna akan pentingnya bela negara dan kecintaan terhadap kearifan lokal dalam rangka meningkatkan rasa nasionalisme.

Teknik observasi dilakukan untuk melihat kondisi pada masyarakat setempat untuk dapat mencari permasalahan yang sedang dihadapi oleh remaja yang berkaitan dengan peningkatan rasa nasionalisme. Wawancara awal dilakukan kepada ketua karang taruna Pulau Untung Jawa guna menganalisis permasalahan yang muncul disana. Dalam wawancara tersebut didapati kondisi remaja disana masih rendah pemahamannya terhadap bela negara dan kearifan lokal yang dimiliki oleh daerah mereka.
Pengabdian kepada masyarakat ini terlaksana atas kerja sama tim dosen Program Studi Pendidikan Pancasila dan Kewarganegaraan Fakultas Keguruan dan Ilmu Pendidikan Universitas Pamulang, yaitu : Dr. H.E. Nurzaman AM.,MM.,M.Si, Drs. H. Alinurdin, M.Pd, Nurdiyana, S.Pd.,MH, Endang Prastini, S.Pd.,MH, Drs. Abdul Kohar, M.Pd, Sucipto,S.Sos.,MM. Pengabdian kepada masyarakat ini terlaksana atas kerjasama antara Prodi PPKn dengan Kelurahan Pulau Untung Jawa.

Kegiatan ini berlangsung dari hari Sabtu sampai Senin, 21-23 September 2019. Kegiatan pengabdian kepada masyarakat di hari pertama dengan melakukan sosialisasi terkait dengan judul kegiatan ini tentang sinergitas aktualisasi bela negara dan kearifan lokal dalam meningkatkan rasa nasionalisme dengan narasumber dari anggota pengabdi yaitu Ibu Endang Prastini, S.Pd.,M.H.

Kegiatan sosialisasi ini juga diselingi dengan sesi tanya jawab antara narasumber dengan para remaja karang taruna di Pulau Untung Jawa. Antusiasme peserta dalam mengikuti kegiatan ini sangat tinggi, hal ini dapat terlihat dari berbagai pertanyaan yang mereka ajukan kepada narasumber.

Metode sosialisasi untuk saat ini dirasa sebagai metode yang sangat tepat dalam upaya meningkatkan pemahaman para remaja terkait dengan tema pada kegiatan 
pengabdian ini, selain ini dengan sosialisasi ini kita juga dapat mengukur tingkat pemahaman mereka terhadap materi yang akan disampaikan.

\section{HASIL DAN PEMBAHASAN}

Remaja Karang Taruna di Pulau Untung Jawa Kepulauan Seribu terdiri dari remaja dengan berbagai latar belakang pendidikan, mulai dari yang masih menjalani pendidikan pada tingkat SMP, SMA ada juga yang sudah bekerja. Pemahaman remaja tersebut terhadap sinergitas bela negara dan kearifan lokal dalam meningkatkan rasa nasionalisme masih perlu ditingkatkan melalui sebuah kegiatan, salah satunya dengan melakukan sosialisasi yang bertujuan untuk memberikan pemahaman kepada para remaja terkait hal tersebut diatas.

Adapun kegiatan pengabdian kepada masyarakat ini dilihat pada gambar 1 .

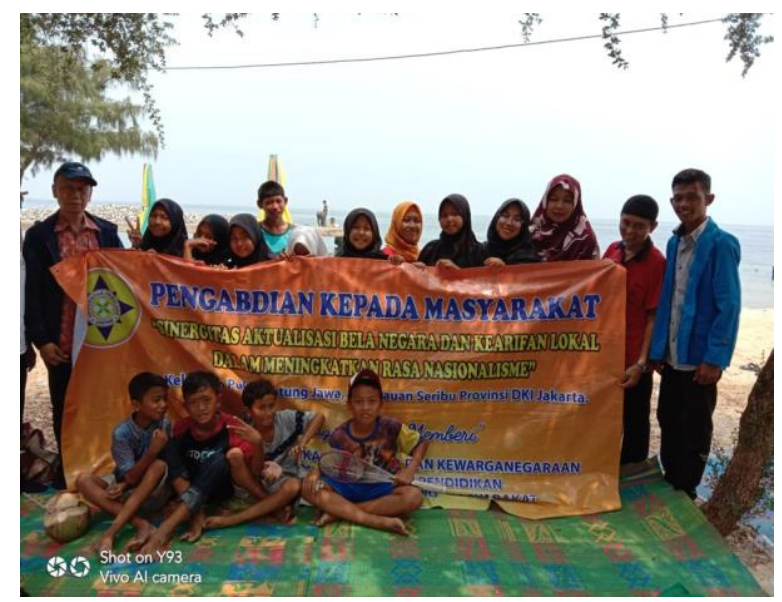

Sumber: Dokumentasi penulis, 2019

Gambar 1. Kegiatan Pengabdian kepada

Masyarakat di Pulau Untung Jawa
Setelah kegiatan sosialisasi oleh tim pengabdi terkait dengan bela negara dan kearifan lokal dalam meningkatkan rasa nasionalisme yang harus dilakukan oleh para remaja sebagai wujud kecintaan mereka terhadap tanah dan air tercinta ini pemahaman para remaja ini meningkat akan arti pentingnya bela negara dan kearifan lokal untuk meningkatkan rasa nasionalisme.

Wawancara yang dilakukan oleh tim pengabdi kepada beberapa remaja tersebut dilakukan guna mengukur seberapa jauh pemahaman mereka akan pentingnya penanaman rasa nasionalisme pada setiap individu, apalagi secara geografis remaja ini bertempat tinggal yang jauh dari pusat kota, sehingganya dirasa sangat perlu untuk menanamkan rasa nasionalisme yang tinggi kepada para remaja tersebut, agar kecintaan mereka terhadap tanah dan air ini semakin besar.

Kegiatan sosialisasi yang dilakukan oleh tim pengabdi mendapat antusiasme yang tinggi dari para remaja karang taruna tersebut, mereka merasakan sendiri manfaat dari kegiatan ini sangat besar dalam merubah cara pandang mereka sebagai warga negara agar bisa menjadi warga negara yang baik yang memiliki kecintaan yang tinggi terhadap bangsa dan tanah air. 
Bela negara adalah sebuah konsep yang disusun oleh perangkat perundangan dari petinggi suatu negara tentang patriotism seseorang, suatu kelompok atau seluruh komponen dari suatu negara dalam kepentingan mempertahankan eksistensi negara tersebut.

Bela negara adalah suatu keharusan yang dilakukan oleh setiap warga negara sebagai wujud kecintaan kita terhadap tanah air yang dapat dilakukan dengan berbagai cara. Jika dulu pada masa sebelum kemerdekaan, wujud bela negara adalah dengan ikut mengangkat senjata untuk melawan penjajah, namun untuk saat ini wujud bela negara yang dapat dilakukan oleh para remaja adalah dengan mengisi kemerdekaan ini dengan hal-hal yang positif.

Bela negara yang dapat dilakukan oleh para remaja karang taruna di Pulau Untung Jawa antara lain adalah dengan belajar yang rajin untuk mengejar cita-cita, mencintai dan menjaga lingkungan dengan baik, berprestasi dalam berbagai bidang dan masih banyak lagi wujud bela negara yang dapat dilakukan oleh para remaja tersebut.

Selanjutnya adalah kearifan lokal, dimana kearifan lokal biasanya diwariskan secara turun temurun dan berlaku secara universal dan parsial. Secara universal artinya adalah nilai-nilai kearifan lokal diterima dan diakui oleh semua orang atas eksistensinya, sedangkan secara parsial sendiri dapat diartikan bahwa setiap daerah dan masyarakat tertentu memiliki kearifan lokal sendiri yang tetap dijaga tidak hanya sebagai sebuah tradisi, namun sebagai pedoman hidup.

Secara garis besar kearifan lokal dapat memperkokoh semangat bela negara sehingga mendukung terwujudnya rasa nasionalisme warga negara. Kearifan lokal yang dimiliki oleh masyarakat Pulau Untung Jawa yang memang sudah menjadi kebiasaan yang dijalankan terus menerus ini diharapkan dapat lebih mempererat rasa persaudaraan diantara sesama serta dapat lebih mengikat dan meningkatkan kecintaan mereka terhadap tanah air ini.

Tongkat estafet perjuangan bangsa berada di tangan generasi muda, sehingga sangat penting adanya regenerasi untuk berkontribusi dalam melestarikan kearifan local di Pulau Untung Jawa. Sebagaimana penelitian yang dilakukan Nursyifa (2018) bahwasanya pengembangan objek wisata sangat penting dilakukan generasi muda untuk dapat diberdayakan dalam hal ide, tenaga, wawasan, kemampuan yang berbasis kearifan lokal sehingga sumber daya manusia dapat memajukan objek wisata. Berdasarkan penelitian tersebut sangat penting disadari bahwa peran remaja karang taruna di Pulau Untung Jawa harus dapat diberdayakan dengan baik, sehingga rasa kecintaan 
terhadap kearifan local yang dimilikinya dapat menumbuhkan semangat nasionalisme dikalangan remaja. Lewat kearifan local yang ada menjadi alat kontrol dari dampak negatif pergaulan bebas yang dapat mengintai remaja. Sebagaimana hasil pengabdian kepada masyarakat yang pernah dilakukan oleh Sulastri, Hayati, \& Nursyifa (2020) dalam upaya mencegah kenakalan remaja dengan memperkuat benteng diri para remaja salah satunya dengan melakukan kegiatan positif termasuk melestarikan budaya yang ada disekitarnya.

Upaya meningkatkan rasa nasionalisme remaja dapat dilakukan oleh berbagai pihak diantaranya: keluarga yang menjadi panutan utama dalam bersikap dan berperilaku, sekolah, masyarakat, maupun pemerintah.

Membela negara bukan hanya diwujudkan dengan mengangkat senjata namun berkontribusi nyata terhadap bangsa dengan apa yang dimiliki agar dapat berguna bagi masyarakat luas dan ditunjukkan pada kegiatan sehari-hari. Sebagaimana penelitian yang dilakukan Sholihatin, Kusnarto, dan Warsiman (2020) nilai-nilai bela negara dengan nilai kearifan lokal masyarakat dapat dilihat dalam bentuk bela negara di lingkungan masyarakat dilakukan dalam kehidupan sehari-hari. Bela negara yang dapat dilakukan remaja dilakukan dengan cara melakukan apa dapat dilakukan para remaja untuk berkontribusi memajukan wilayahnya, misalnya dengan melakukan berbagai kegiatan positif, menghasilkan karya yang inovatif, membuat kreativitas dari sumber daya yang ada, serta mengasah keterampilan yang dimiliki, untuk memajukan objek wisata Pulau Untung Jawa.

\section{KESIMPULAN}

Remaja karang taruna Pulau Untung Jawa ini diharapkan memiliki semangat baru untuk lebih merasa sebagai bagian dari Negara Kesatuan Republik Indonesia yang dapat mewujudkan bentuk bela negara mereka sebagai remaja dengan melakukan hal-hal positif yang dapat menguntungkan diri pribadi mereka sendiri dan bangsa ini tentunya serta semakin mencintai kearifan lokal yang sudah ada dan mentradisi dalam masyarakat guna meningkatkan rasa nasionalisme

\section{REFERENSI}

Lastri, S., Hayati, E., \& Nursyifa, A. (2020). Dampak Kenakalan Remaja Untuk Meningkatkan Kesadaran Dari Bahaya Kenakalan Remaja Bagi Masa Depan. Jurnal Loyalitas Sosial: Journal of Community Service in Humanities and Social Sciences, 2(1), 15-24.

Nursyifa, A. (2018). Kajian Cultural Lag dalam Kehidupan Masyarakat 
Perkampungan Budaya Betawi Setu

Babakan Pada Era Globalisasi. Jurnal

Pendidikan Kewarganegaraan, 5(1), 1-

24.

UUD Republik Indonesia Tahun 1945 Pasal

27 Ayat (3) dan Pasal 30 Ayat (1).

Sholihatin, E., Kusnarto, K., \& Warsiman, W.

(2020). HARMONISASI NILAI-

NILAI BELA NEGARA DENGAN

SISTEM NILAI KEARIFAN LOKAL
MASYARAKAT

UNTUK

MENINGKATKAN

NASIONALISME.

Public

Administration Journal of Research, 2(2), 139-151.

Subagyo, A. (2015). Bela Negara : Peluang dan Tantangan di Era Globalisasi. Yogyakarta : Graha Ilmu 